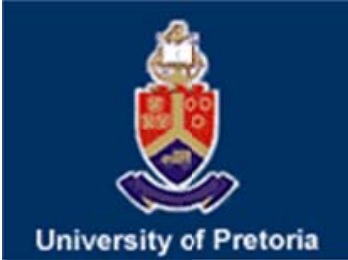

University of Pretoria Department of Economics Working Paper Series

Tax Competition, Policy Competition and the Strategic Use of Policy Restrictions on Foreign Direct Investments

Kaushal Kishore

University of Pretoria

Working Paper: 2016-84

November 2016

Department of Economics

University of Pretoria

0002, Pretoria

South Africa

Tel: +27 124202413 


\title{
Tax Competition, Policy Competition and the strategic use of Policy Restrictions on Foreign Direct Investments (First draft: Comments welcome)
}

\author{
Kaushal Kishore* \\ Senior Lecturer \\ Department of Economics \\ University of Pretoria \\ Pretoria \\ South Africa \\ 0002
}

November 17, 2016

\begin{abstract}
In a dynamic two-period model of tax competition where competing countries strategically choose foreign investment restrictions which increases sunk cost of investments, we show that choosing a higher level of restriction is beneficial for the competing countries. A higher level of restriction reduces competition and increases tax revenue in the later period, which allows the government to offer large tax holidays during the initial period of investment. The result is counter-intuitive as it is widely believed that sunk cost reduces foreign direct investments. Moreover, even though competing countries are ex-ante symmetric, equilibrium choice of the level of restrictions may not be equal. The result provides sunk cost as another rationale for tax holidays in the presence of competition.
\end{abstract}

JEL classification: F21; H21; H25; H87

Keywords: Dynamic Tax Competition; Non-preferential regime; Ownership restrictions; Foreign Direct Investment

*I am thankful to Alexander Zimper, Eva Li and seminar participants at the University of Pretoria for their valuable comments and suggestion. All errors are mine. Email: kaushal.kishore@up.ac.za. Ph: +27721032029. 


\section{Introduction}

There is a huge literature on policy competition for foreign direct investments ${ }^{1}$. Countries offer tax holidays and other form of benefits to attract foreign direct investments. Given the nature of competition and increasing mobility of multinational firms (MNFs) it seems it is beneficial for competing countries to choose more liberal policies and remove restrictions on foreign direct investments. But many developing as well as developed countries continue to impose some sort of restrictions on FDI. The kind of restriction we have in mind is ownership restrictions or indigenisation requirements ${ }^{2}$. Ownership restrictions is likely to affect ownership patterns of firms and which in turn affect the productivity of multinational ${ }^{3}$. In this paper, we use restrictions on foreign investments and ownership restriction interchangeably.

There is a large literature on "tax competition." Authors argue that due to increasing mobility of multinationals, the capital is being taxed at an alarmingly low rate. Tax competition for multinationals leads to "race to bottom" ${ }^{4}$ effect where multinationals are not taxed at all. Given the nature of competition, one expects a similar effect on policies which imposes restrictions on foreign direct investments $^{5}$. In the empirical literature, Rodrik (1997) and Devereux et al. (2008) finds that the relaxation of capital controls stimulates tax competition and thus reduces both statutory and effective tax rates. Hence, it is not clear why so many countries continue to impose restrictions on foreign ownership ${ }^{6}$. Increasingly, more foreign direct investments are done through merger and acquisition and joint venture ${ }^{7}$. It is observed that M\&A are affected more by short-term fluctuation and are often opportunist. Therefore, it can be argued that foreign investments through M\&A are more mobile across jurisdictions compared to greenfield investments ${ }^{8}$. Ownership restrictions affect the mobility of the firm, because if the firm wants to move to another country in the future, the cost may be higher when ownership restriction is high. Changing the ownership requires costly bargaining between domestic and foreign entities. Given that the firm owner knows it, everything else being equal, a firm would like to move to the country with least restrictions on $\mathrm{FDI}^{9}$.

\footnotetext{
${ }^{1}$ See for example Bjorvatna and Eckel (2006), Straub (2008), Kesternich and Schnitzer (2010), Janeba (2000), Janeba (2002), Fredriksson and Millimet (2002).

${ }^{2}$ As noted in Karabay (2014), over the years many countries (both developing and developed) have employed some kind of indigenisation policy. Indigenisation is defined by Katrak (1983) as the requirement that the host country imposes on an investor to share ownership of an affiliate with residents in the host country. Many countries have a policy that allows FDI only through ventures with local firms (OECD 2007). Imposing a joint venture is similar to ownership restrictions in that they require the MNF to offer a minimum profit share to the domestic partner.

${ }^{3}$ See Desai and Hines (2004)

${ }^{4}$ See Baldwin and Krugman (2004).

${ }^{5}$ See Desai, Foley and Hines (2004).

${ }^{6}$ See Golub and Koyama (2006), Golub (2003).

${ }^{7}$ See Becker and Fuest (2010).

${ }^{8}$ See Davies, Desbordes and Ray (2015)

${ }^{9}$ See for example: Schnitzer (1999), Eaton and Gersovitz (1983), Thomas and Worrall (1994), Chisik and Davies (2004).
} 
Authors have found rationales for having such ownership restrictions in the presence of asymmetric information between MNF and the host country government ${ }^{10}$. But in a full information scenario, the justification for having restrictions on foreign investments is not entirely understood.

This paper is related to Doyle and Wijnbergen (1994). In this paper, a multinational incurs a sunk cost once an investment is made in the host country and the investor has an outside option. He shows that "tax holidays" occurs in the equilibrium and is increasing in sunk cost. We consider a scenario where two identical countries compete to attract the investor over time. In our paper competing countries choose sunk cost strategically and simultaneously. Therefore, we take into account the effect of competition and strategic interaction between tax rates and sunk costs in competing countries.

Becker and Fuest (2011) find that the introduction of merger and acquisition (M\&A) investment intensifies tax competition because it gives rise to an additional negative fiscal externality. In this paper, investors decide the level of M\&A. In our paper, restrictions on foreign investments only affect an investor when he/she wishes to relocate to another jurisdiction in the future.

Janeba (2000) shows that when the host government cannot commit to future tax rates, a foreign investor has the incentive to create capacity in another country to counter a future increase in tax rates. Extra capacity in another country creates competition between two countries which has a negative impact on the tax rate. If the cost of creating extra capacity (cost of mobility) is low, the tax rate is also low. In our paper, competing countries strategically choose the cost of mobility of the firm. This paper tries to explain this strategic interaction when competing countries can influence this cost of relocation through restrictions on foreign ownership.

This paper is also related to Bond and Samuelson (1986). In the presence of asymmetric information, he argues that when two asymmetric countries compete to attract a foreign investor, a more productive country offers a larger "tax holidays" in the initial period to signal its high productivity. In this paper, we show that a country may choose a high level of policy restriction to reduce competition in the later period which increases tax revenue. The government can use the future gain in tax revenue to offer large tax holidays in the initial period and attract investments. Therefore, we propose ownership restrictions as another rationale for offering large tax holidays.

This paper is also related to Lee (1997). In a dynamic two-period model Lee(1997) shows that when capital is perfectly mobile and in period one but imperfectly mobile (due to transaction cost) in the later period, tax rates in competing countries is higher in the later period which results in over provision of the public good. In Lee(1997) the transaction cost is exogenously given while, in this paper transaction cost is endogenously determined. Competing countries strategically and simultaneously choose applicable transaction cost. Also while in Lee(1997) there is only imperfectly mobile capital in a later period, in this

\footnotetext{
${ }^{10}$ See for example Dasgupta and Sengupta (1995), Karabay (2010), Karabay, Pulvener and Weinmuller (2009).
} 
paper we have both perfectly mobile and imperfectly mobile capital in a later period.

This paper is also related to a large literature on tax competition with multiple instruments ${ }^{11}$. While the literature has considered multiple tax instruments and public good provisions which can affect the mobility of the capital, the strategic use of policy restrictions on foreign direct investments is not considered.

We consider a dynamic two-period model of tax competition under a nonpreferential taxation scheme, ${ }^{12}$ where two symmetric competing countries strategically and simultaneously choose level of restriction on foreign ownership. A higher restriction on foreign ownership increase the sunk cost of investments and therefore, increases the cost of mobility. We show that one of the competing countries has an incentive to choose a higher level of ownership restriction. A higher ownership restriction increases investments and also increase equilibrium tax rates and tax revenues of competing countries. A higher cost of mobility decreases competition for mobile capital in the later period and increases tax revenue. The government can use a higher tax revenue in the future to offer large tax rebates during the initial period and attract investments. Moreover, even though countries are ex-ante symmetric, equilibrium choice of policy restrictions imposed on foreign investments are not equal. While one of the competing countries choose to impose the maximum restriction on foreign investments, the other country may choose any feasible level of restrictions, including no restriction on foreign investments.

\section{Model}

There are two identical countries/jurisdictions indexed by $i \in\{A, B\}$, who compete to attract capital from the outside their jurisdictions. Each government uses two policy choices at its disposal to attract investments: tax rate and policy restrictions on foreign direct investments. A government can reduce the tax rate to attract investments and it can also increase (reduce) policy restrictions on foreign direct investments which decrease (increase) sunk cost of investments. For example, most countries set The economy lasts for two periods, 1 and 2 . At the beginning of period 1 , competing countries jointly adopt a non-preferential taxation scheme. Under a non-preferential taxation scheme a government is restricted to set an equal tax rate on domestic and foreign capital. After this

\footnotetext{
${ }^{11}$ See for example Wilson (1995), Brueckner (2004), Braid (1996), Braid (2000), Braid(2005), Braid (2013)

${ }^{12}$ In recent years, concerned by the perceived "harmful effects" of such preferential measures adopted competitively by large number of countries, several international agreements and non-binding resolutions have been adopted by the European Union (EU) and Organization for Economic Co-operation and Development (OECD) in order to impose restrictions on preferential taxation among member countries and to take joint action against continuation of preferential tax regimes by non-member countries. One of the main policy recommendation is to follow a non-preferential taxation scheme which restricts government from setting different tax rates based on nationality and mobility of the capital. See OECD (1997).
} 
decision is made, competing countries simultaneously choose the level of policy restrictions on foreign direct investments. The level of policy restrictions is captured by the term $\lambda_{i}(i=A, B)$, where $0 \leq \lambda_{i} \leq 1$. If an investor invests in country $i$ and he wants to move out of the country in a later period, he can only take a fraction $\lambda_{i}$ of invested capital. In other words, $\lambda_{i}$ captures sunk cost of investment in country $i$. We assume that competing country cannot commit to future tax rates. In each period there is a single investor (residing outside the competing countries) who wishes to invest either in country $A$ or country $B$. Each investor has a unit of capital to invest. For simplicity, we assume that in the beginning of period 1, competing countries has no domestic capital. Return on capital outside the two competing countries is zero and return on capital in two competing countries is equal to one. We also assume that there is no cost of moving to country $A$ or country $B$ from outside.

At the beginning of period 1, competing countries choose tax rates applicable in period 1. Because competing countries have no domestic capital in the beginning, irrespective of whether they have jointly adopted a preferential (nonpreferential) taxation scheme, each country announces a single tax rate applicable on foreign capital. The investor observes the tax regime, policy restrictions and tax rates adopted by two countries and invests in country $A$ (country $B$ ) or remain outside. At the beginning of period 2, competing countries announce tax rate applicable for period 2. If competing countries adopt a non-preferential taxation scheme, they announce a single tax rate applicable on both domestic and foreign capital. If competing countries adopt a preferential taxation scheme then the country which receives the investor period 1, announces different tax rates applicable on domestic and foreign capital. The new investor observes tax rates and investment decision made by the investor in period 1 and decides whether to invest in country $A$ or country $B$. If the investor in period 1 had invested in country $A$ (country $B$ ), he decides whether to remain in country $A$ (country $B$ ) or relocate to country $B$ (country $A$ ). Note that if the investor decides to move from country $A$ (country $B$ ) in period 2 , he can only take away a fraction $\lambda_{A}\left(\lambda_{B}\right)$ of invested capital to country $B$ (country $A$ ). We assume that the governments and investors are fully rationale and can predict the future outcome of the game. We assume that the governments maximize tax revenue and investors maximize after-tax returns on investments. For simplicity, we assume that neither governments nor investors discount future income. We analyze the subgame perfect Nash equilibrium of the game. The timing of the game are as follows:

1. Competing countries jointly adopt a non-preferential taxation scheme.

2. Competing countries simultaneously choose policy restriction on foreign direct investments which is captures by $\lambda_{i}(i=A, B)$.

3. Competing countries simultaneously announce tax rate applicable to foreign investments in period 1.

4. The investor observes tax rates of two countries and makes investment decision. 
5. At the beginning of period 2, competing countries simultaneously announce tax rates applicable in period 2. Under a preferential taxation scheme, the country which receives an investment in period 1, announces different tax rates for domestic and foreign capital. The country which does not receive an investment in period 1 announces a tax rate applicable to foreign investments. Under a non-preferential taxation scheme, both countries are restricted to announce a single tax rate on domestic and foreign capital.

6. The new investor observes tax rates and decides whether to invest in country $A$ or country $B$. The investor from period 1 decide to stay invested in country $A$ (country $B$ ) or relocate to country $B$ (country $A$ ).

We assume that competing countries can fully commit to tax rates and policy restrictions within a time-period, i.e. they cannot change renege on tax rates or policy restrictions within a time-period. Moreover, competing countries cannot commit to future tax rates. Governments and investors are risk neutral. Governments and investors are rational, i.e., they can fully predict the outcome of the game. We solve for subgame perfect Nash equilibrium of this dynamic game by backward induction method. In the next section, we look at tax competition between competing countries after the choice of ownership restrictions are made by competing countries simultaneously.

\section{Tax Competition}

We solve the game by backward induction method. Firstly, we look at the outcome of tax competition in period 2. Under a non-preferential taxation scheme, a country is restricted to set an equal tax rate for domestic and foreign capital. Let $\lambda_{i}(i=A, B)$ be the level of policy restrictions chosen by country $i$. We solve the outcome of this game by Backward Induction method. Firstly, we look at outcomes in period 2 .

\subsection{Tax Competition in period two}

Without a loss of generality, suppose country $A$ is successful in attracting the investor in period 1 . Note that at this point in time, no assumption regarding the level of policy restriction chosen by country $A$ is made. Country $A$ can be the country which chooses a higher or a lower level of policy restriction. For easy of notation suppose the level of policy restriction chosen by country $A$ is $\lambda$, i.e. $\lambda_{A}=\lambda$. Because the investor can take away a fraction $\lambda$ of capital if he wishes to relocate to country $B$ in period 2 , country $B$ has to undercut the tax rate of country $A$ by a discrete margin if it wishes to attract the investor. Suppose the tax rate chosen by country $A$ be $t_{A}$. The after-tax return on capital in country $A$ is equal to $1-t_{A}$. If country $B$ sets $t_{B}$ and the investor choose to relocate to country $B$, his after-tax return on investment is $\lambda\left(1-t_{B}\right)$. Therefore, he will 
relocate to country $B$ when

$$
\begin{aligned}
1-t_{A} & \leq \lambda\left(1-t_{B}\right) \Leftrightarrow \\
t_{B} & \leq 1-\left(\frac{1-t_{A}}{\lambda}\right) .
\end{aligned}
$$

When $\lambda$ is low, country $B$ has to undercut the tax rate of country $A$ by a larger margin to attract the investor. Country $A$ is able to keep its domestic investor as long as $t_{B}>1-\left(\frac{1-t_{A}}{\lambda}\right)$. Countries also compete for the new investor who can relocate to the country which offers him a lower tax rate because he is fully mobile across competing countries. Country $A$ is able to keep its domestic investor and attract the new investor as well if it sets $t_{A} \leq t_{B}$. For simplicity, we assume that if the tax rates are same, i.e. $t_{A}=t_{B}$, the investor prefer to invest in country $A$. Hence, the tax revenue of country $A$ can be represented as:

$$
T R_{A}^{2}=\left\{\begin{array}{ccc}
t_{A} & \text { if } 1-\left(\frac{1-t_{A}}{\lambda}\right) \leq t_{B}<t_{A} \\
2 t_{A} & \text { if } t_{A} \leq t_{B} \\
0 & \text { if } t_{B}<1-\left(\frac{1-t_{A}}{\lambda}\right)
\end{array} .\right.
$$

From (2), we observe that as country $A$ reduces its tax rate, country $B$ has to offer a larger tax rebate to attract the investor from country $A$. At lower tax rate, tax gain main be less of concern for the firm. Costs of tax planning to further reduce the tax rate may also be high at a low tax rate. Country $B$ has no domestic capital at the beginning of period 2. Therefore, it can only receive positive tax revenue if it undercuts the tax rate of country $A$ by a small margin and attracts the new investor in period 2. It can also attract the domestic investor of country $A$ if it undercuts the tax rate of country $A$ by a discrete margin, i.e. sets $t_{B}<1-\left(\frac{1-t_{A}}{\lambda}\right)$. Hence, the tax revenue of country $B$ can be represented as:

$$
T R_{B}^{2}=\left\{\begin{array}{lr}
0 & \text { if } t_{A} \leq t_{B} \\
t_{B} & \text { if } 1-\left(\frac{1-t_{A}}{\lambda}\right)<t_{B}<t_{A} \\
(1+\lambda) t_{B} & \text { if } t_{B}<1-\left(\frac{1-t_{A}}{\lambda}\right)
\end{array} .\right.
$$

What we observe in (2), that as the tax rate of country $A$ decreases, it becomes harder for country $B$ to undercut country $A$ and attract capital.

Proposition 1 When $\lambda=1$, in a unique pure strategy Nash equilibrium, competing countries set an equal tax rate which is equal to zero. When $\lambda<1$, a pure strategy Nash equilibrium of the game described above does not exist.

Proof. When $\lambda=1$, both investors are perfectly mobile between two countries and Bertrand type tax competition leads to tax rate equal to zero. It is easy to argue that no country can do better by a unilateral deviation. When $\lambda<1$, then investor $I_{1}$ has to incur a positive sunk cost to relocate to country $B$. Suppose there is a symmetric pure strategy Nash equilibrium where $t_{A}=t_{B}>0$. In this case country $B$ does not receive an investment, hence, it has an incentive 
to set a tax rate marginally lower than $t_{A}$ and attract investor $I_{2}$ and receive positive tax revenue. Hence, a symmetric pure strategy Nash equilibrium does not exist. Suppose there is an asymmetric pure strategy Nash equilibrium where $t_{A}>t_{B} \geq 0$. If in this equilibrium country $B$ is able to attract investor $I_{1}$ then country $A$ has an incentive to lower its tax rate. If country $B$ is not able to attract investor $I_{1}$ then country $A$ has an incentive to increases its tax rate. Hence, a pure strategy Nash equilibrium of the game does not exist when $\lambda<1$.

Given we don't have a pure strategy Nash equilibrium, we analyze a mixed strategy Nash equilibrium ${ }^{13}$. Proposition 2 describes the equilibrium outcome of tax competition in period 2. Country $A$ which attracts the investor in period 1 receives higher tax revenue compared to country $B$. The maximum tax rate country $A$ can set to completely discourage country $B$ from undercutting by a large amount to attract the investor in country $A$ is $\left(1-\lambda^{2}\right)$. Therefore, the maximum tax rate of country $A$ in equilibrium is $\left(1-\lambda^{2}\right)$. Country $A$ does not set a tax rate lower than $\frac{1}{2}\left(1-\lambda^{2}\right)$ because even if it attract the new investor its tax revenue is equal to $\left(1-\lambda^{2}\right)$ which it can obtain by receiving taxes from its domestic investor. Therefore, competing countries randomize over $\left[\frac{1}{2}\left(1-\lambda^{2}\right),\left(1-\lambda^{2}\right)\right]$. By setting tax rate equal to $\frac{1}{2}\left(1-\lambda^{2}\right)$, country $B$ can attract the new investor with probability one. Therefore, equilibrium tax revenue of country $B$ is equal to $\frac{1}{2}\left(1-\lambda^{2}\right)$. A similar mixed strategy is also discussed in Narasimhan (1988) among others.

Proposition 2 When $\lambda<1$, in a mixed strategy Nash equilibrium, country $A$ and country $B$ receive $\left(1-\lambda^{2}\right)$ and $\frac{1}{2}\left(1-\lambda^{2}\right)$ respectively, as tax revenue. Competing countries randomize over the support $\left[\frac{1}{2}\left(1-\lambda^{2}\right),\left(1-\lambda^{2}\right)\right]$. Equilibrium tax revenues of competing countries decrease monotonically as $\lambda$ increases. Distribution of taxes over the support of country $A$ and country $B$ denoted as $F_{A}$ and $F_{B}$ respectively, are:

$$
\begin{aligned}
& F_{B}=1-\frac{1}{t}\left(1-\lambda^{2}-t\right) \\
& F_{A}=1-\frac{1}{2 t}\left(1-\lambda^{2}\right) .
\end{aligned}
$$

Proof. When $\lambda>1$, country $B$ can not only attract investor $I_{2}$, it can also attract investor $I_{1}$ from country $A$. Let $t_{A}^{\max }$ be the maximum tax rate of country $A$ such that country $B$ has no incentive to undercut country $A$ by a large margin and attract domestic investor $I_{1}$. If country $A$ sets $t_{A}=t_{A}^{\max }$ then the maximum tax rate country $B$ can set to attract investor $I_{1}$ is

$$
1-\left(\frac{1-t_{A}^{\max }}{\lambda}\right) .
$$

\footnotetext{
${ }^{13}$ For mixed strategy in tax competition see for example; Wilson (2005), Janeba (2000), Wang (2004), Konrad and Kovenock (2009).
} 
If country $B$ sets $1-\left(\frac{1-t_{A}^{\max }}{\lambda}\right)$, it will not only attract new investments, it will also attract investment from country $A$. The total tax revenue of country $B$ in this case is equal to

$$
(1+\lambda)\left[1-\left(\frac{1-t_{A}^{\max }}{\lambda}\right)\right] .
$$

If country $B$ decides not to attract investment from country $A$ and satisfied with the new investment, its tax revenue is $t_{A}^{\max }$. Country $B$ will not undercut if

$$
\begin{aligned}
t^{\max } & =(1+\lambda)\left[1-\left(\frac{1-t^{\max }}{\lambda}\right)\right] \\
t^{\max } & =(1+\lambda)-\frac{1+\lambda}{\lambda}+t^{\max }\left(\frac{1+\lambda}{\lambda}\right) \Leftrightarrow \\
t^{\max }\left(1-\frac{1+\lambda}{\lambda}\right) & =(1+\lambda)\left(1-\frac{1}{\lambda}\right) \Leftrightarrow \\
t^{\max }\left(-\frac{1}{\lambda}\right) & =-(1+\lambda)\left(\frac{1-\lambda}{\lambda}\right) \Leftrightarrow \\
t^{\max } & =(1+\lambda)(1-\lambda) .
\end{aligned}
$$

When $\lambda>0$, if country $i$ sets $t^{\max }=(1+\lambda)(1-\lambda)$, then country $j$ has no incentive to undercut country $i$ and attract the investor from country $i$. But country $j$ can undercut country $i$ by a small margin and attract the new investor. if country $i$ sets $t^{\max }=\left(1-\lambda^{2}\right)$, it is sure to receive taxes from its domestic investor. The minimum tax rate country $i$ would set is such that it gets at least $\left(1-\lambda^{2}\right)$ if it is able to attract the new investor as well. Let $t^{\text {min }}$ be the minimum tax rate country $i$ sets in equilibrium. If country $i$ sets $t_{i}=t^{\mathrm{min}}$ and it attract the new investments as well, its tax revenue is

$$
\begin{aligned}
2 t^{\min } & =\left(1-\lambda^{2}\right) \Leftrightarrow \\
t^{\min } & =\frac{1}{2}\left(1-\lambda^{2}\right) .
\end{aligned}
$$

To find a mixed strategy Nash equilibrium both countries should earn an equal amount everywhere on the support. Let $F_{A}$ and $F_{B}$ denote distributions of taxes over the support of country $A$ and country $B$. Suppose country $A$ sets $t_{A} \in\left[\frac{1}{2}\left(1-\lambda^{2}\right),\left(1-\lambda^{2}\right)\right]$. It will receive $t_{A}$ from its domestic capital and it will also attract foreign investment with probability $\left[1-F_{B}\left(t_{A}\right)\right]$. Hence, its tax revenue is equal to

$$
t_{A}+t_{A}\left[1-F_{B}\left(t_{A}\right)\right]
$$


Given that a country should earn an equal tax revenue everywhere on the support, we must have

$$
\begin{aligned}
t_{A}+t_{A}\left[1-F_{B}\left(t_{A}\right)\right] & =1-\lambda^{2} \Leftrightarrow \\
t_{A}\left[1-F_{B}\left(t_{A}\right)\right] & =1-\lambda^{2}-t_{A} \Leftrightarrow \\
{\left[1-F_{B}\left(t_{A}\right)\right] } & =\frac{1}{t_{A}}\left(1-\lambda^{2}-t_{A}\right) \Leftrightarrow \\
F_{B}\left(t_{A}\right) & =1-\frac{1}{t_{A}}\left(1-\lambda^{2}-t_{A}\right) .
\end{aligned}
$$

Hence, the distribution of taxes over the support of country $B$ is $1-\frac{1}{t_{A}}\left(1-\lambda^{2}-t_{A}\right)$. Similarly, suppose country $B$ sets a tax rate $t_{B} \in\left[\frac{1}{2}\left(1-\lambda^{2}\right),\left(1-\lambda^{2}\right)\right]$. Country $B$ cannot attract the investor from country $A$ but it will attract foreign investor with a positive probability $\left[1-F_{A}\left(t_{B}\right)\right]$. Hence, its expected tax revenue is $t_{B}\left[1-F_{A}\left(t_{B}\right)\right]$. Given that a country should earn an equal amount everywhere on the support, we must have

$$
\begin{aligned}
t_{B}\left[1-F_{A}\left(t_{B}\right)\right] & =\frac{1}{2}\left(1-\lambda^{2}\right) \Leftrightarrow \\
{\left[1-F_{A}\left(t_{B}\right)\right] } & =\frac{1}{2 t_{B}}\left(1-\lambda^{2}\right) \Leftrightarrow \\
F_{A}\left(t_{B}\right) & =1-\frac{1}{2 t_{B}}\left(1-\lambda^{2}\right) .
\end{aligned}
$$

Now, we need to show that no country has an incentive to deviate unilaterally. Note that country $A$ has no incentive to set a tax rate lower than $\frac{1}{2}\left(1-\lambda^{2}\right)$ and country $B$ has no incentive to undercut country $A$ by an amount large enough to attract the investor from country $A$. Only thing left to be proved is that country $A$ has no incentive to increase its tax rate. Note that if country $A$ increases its tax rate, it will lose its domestic capital with a positive probability. Suppose country $A$ sets a tax rate $t_{A}=\left(1-\lambda^{2}+\epsilon\right)$ where $\in>0$. From (4), the tax revenue of country $A$ is:

$$
\begin{aligned}
& 1-\left[1-\frac{1}{\frac{1-\lambda^{2}}{2}+\epsilon}\left(1-\lambda^{2}-\frac{1-\lambda^{2}}{2}-\epsilon\right)\right]\left(1+\epsilon-\lambda^{2}\right) \\
= & \frac{1}{\frac{1-\lambda^{2}}{2}+\epsilon}\left(1-\lambda^{2}-\frac{1-\lambda^{2}}{2}-\epsilon\right)\left(\frac{1-\lambda^{2}}{2}+\epsilon+\frac{1-\lambda^{2}}{2}\right) \\
= & \left(\frac{1-\lambda^{2}}{2}-\epsilon\right)+\frac{1-\lambda^{2}}{2}\left(\frac{\frac{1-\lambda^{2}}{2}-\epsilon}{\frac{1-\lambda^{2}}{2}+\epsilon}\right)
\end{aligned}
$$

The first term of (6) is clearly decreasing with $\in$ and numerator of the second term is decreasing with $\in$ and the denominator is increasing with $\in$. Therefore, country $A$ has no incentive to unilaterally deviate from the proposed strategy for a mixed strategy Nash equilibrium. 


\subsection{Tax Competition in period one}

Let $\lambda_{A}$ and $\lambda_{B}$ be the level of policy restrictions chosen by country $A$ and country $B$, respectively. Without a loss of generality we assume that $\lambda_{A} \leq$ $\lambda_{B} \Leftrightarrow 1-\lambda_{A}^{2} \geq 1-\lambda_{B}^{2}$, i.e., country $A$ imposes a higher level of restriction on foreign direct investments. Tax revenue of competing countries in period 2 depends on the level of restriction chosen by the country which is successful in attracting the investor in period 1 . The country which is successful in attracting the investor in period 1 receives $\left(1-\lambda^{2}\right)$ in period 2 , while the another country receives $\frac{1}{2}\left(1-\lambda^{2}\right)$. Hence, if country $A$ is successful in attracting the investor in period 1 , it receives $\left(1-\lambda_{A}^{2}\right)$ and when it is not successful in attracting the investor it receives $\frac{1}{2}\left(1-\lambda_{B}^{2}\right)$.

Proposition 3 When $\left(1-\lambda_{B}^{2}\right) \geq \frac{1}{2}\left(1-\lambda_{A}^{2}\right)$ country $A$ and country $B$ receive an equal amount $\frac{1}{2}\left(1-\lambda_{A}^{2}\right)$ as tax revenue.

Proof. In this case a country receives higher tax revenue if it is successful in attracting the investor in period 1. Country $A$ has a higher level of ownership restriction compared to country $B$. Therefore, country $A$ is more aggressive in period 1. The difference in tax revenue of country $B$ if it is successful in attracting the investor in period 1 compared to the case when it is not able to attract the investor in period 1 is $\left(1-\lambda_{B}^{2}\right)-\frac{1}{2}\left(1-\lambda_{A}^{2}\right)$. Hence, in order to attract the investor, the minimum tax rate country $B$ sets in period 1 is equal to $\frac{1}{2}\left(1-\lambda_{A}^{2}\right)-\left(1-\lambda_{B}^{2}\right)$. If the investor relocate to country $B$ at $t_{1}=$ $\frac{1}{2}\left(1-\lambda_{A}^{2}\right)-\left(1-\lambda_{B}^{2}\right)$, then in period 2 his expected tax payment is equal to

$$
\begin{aligned}
& \int_{\frac{1}{2}\left(1-\lambda_{B}^{2}\right)}^{\left(1-\lambda_{B}^{2}\right)}\left(1-\frac{1}{2 t}\left(1-\lambda_{B}^{2}\right)\right) d t \\
= & \int_{\frac{1}{2}\left(1-\lambda_{B}^{2}\right)}^{\left(1-\lambda_{B}^{2}\right)} d t-\frac{1-\lambda_{B}^{2}}{2} \int_{\frac{1}{2}\left(1-\lambda_{B}^{2}\right)}^{\left(1-\lambda_{B}^{2}\right)} \frac{1}{t} d t \\
= & \frac{1}{2}\left(1-\lambda_{B}^{2}\right)(2-\ln 2) .
\end{aligned}
$$

Hence, his total tax payment is equal to

$$
\begin{aligned}
& \frac{1}{2}\left(1-\lambda_{A}^{2}\right)-\left(1-\lambda_{B}^{2}\right)+\frac{1}{2}\left(1-\lambda_{B}^{2}\right)(2-\ln 2) . \\
= & \frac{1}{2}\left(1-\lambda_{A}^{2}\right)-\frac{1}{2} \ln 2 .
\end{aligned}
$$

From (8) it is clear that the expected tax payment can be positive or negative depending on the value of $\lambda_{A}$. If the investor move to country $A$ its expected tax payment in period 2 is $\frac{1}{2}\left(1-\lambda_{A}^{2}\right)(2-\ln 2)$. Therefore, if country $A$ wishes to attract the investor in period 2 , the maximum tax rate it can in period 1 is 
$T$ such that

$$
\begin{aligned}
T+\frac{1}{2}\left(1-\lambda_{A}^{2}\right)(2-\ln 2) & \leq \frac{1}{2}\left(1-\lambda_{A}^{2}\right)-\frac{1}{2} \ln 2 \Leftrightarrow \\
T & \leq \frac{1}{2}\left(1-\lambda_{A}^{2}\right)-\frac{1}{2} \ln 2-\frac{1}{2}\left(1-\lambda_{A}^{2}\right)(2-\ln 2) \Leftrightarrow \\
T & \leq-\frac{1}{2}\left(1-\lambda_{A}^{2}\right) .
\end{aligned}
$$

Therefore country $A$ can set the tax rate equal to $-\frac{1}{2}\left(1-\lambda_{A}^{2}\right)$ in period 1 and attract the investor. Tax revenue of country $A$ in period 1 and period 2 are $-\frac{1}{2}\left(1-\lambda_{A}^{2}\right)$ and $\left(1-\lambda_{A}^{2}\right)$, respectively. Hence, the total tax revenue of country $A$ is equal to $\frac{1}{2}\left(1-\lambda_{A}^{2}\right)$. If country $A$ does not attract the investor in period 1 its tax revenue is equal to $\frac{1}{2}\left(1-\lambda_{B}^{2}\right)$ which is strictly less than $\frac{1}{2}\left(1-\lambda_{A}^{2}\right)$. Hence, it is beneficial for country $A$ to attract the investor in period 1 .

Proposition 3 describes the equilibrium outcome when a country earn higher tax revenue when it is able to attract the investor in period 1. The outcome only depends on the level of restrictions imposed by the country which imposed a higher level of restriction. The reason is; the investor from period 1 needs to be compensated up-front in period 1 for tax payments in period 2. That drives down total tax payments by the investor in period 1 to zero. Therefore, the amount of compensation provided by the country which has a higher restriction on foreign investments does not change.

Proposition 4 When $\frac{1}{2}\left(1-\lambda_{A}^{2}\right) \geq\left(1-\lambda_{B}^{2}\right)$ country $A$ and country $B$ receive an equal amount $\frac{1}{2}\left(1-\lambda_{A}^{2}\right)$ as tax revenue.

Proof. In this case tax revenue of country $B$ is higher in period 2 when country $A$ attract the investor in period 1 . Therefore, in period 1 country $B$ does not set a tax rate lower than $\frac{1}{2}\left(1-\lambda_{A}^{2}\right)-\left(1-\lambda_{B}^{2}\right) \geq 0$. If the investor invests in country $B$ in period 1 then using (7) his expected tax payment is equal to $\frac{1}{2}\left(1-\lambda_{B}^{2}\right)(2-\ln 2)$. Given country $B$ sets $\frac{1}{2}\left(1-\lambda_{A}^{2}\right)-\left(1-\lambda_{B}^{2}\right)$ in period 1 , his total tax payment is equal to

$$
\begin{aligned}
& \frac{1}{2}\left(1-\lambda_{B}^{2}\right)(2-\ln 2)+\frac{1}{2}\left(1-\lambda_{A}^{2}\right)-\left(1-\lambda_{B}^{2}\right) \\
= & \frac{1}{2}\left(1-\lambda_{A}^{2}\right)-\frac{1}{2} \ln 2 .
\end{aligned}
$$

Depending on $\lambda_{A}$, the total tax payment can be positive or negative. If the investor invests in country $A$ his expected tax payment in period 2 is $\frac{1}{2}\left(1-\lambda_{A}^{2}\right)(2-\ln 2)$. Therefore, if country $A$ wishes to attract the investor in period 1, the maximum tax rate it can set is $T^{\max }$ such that

$$
\begin{aligned}
T^{\max }+\frac{1}{2}\left(1-\lambda_{A}^{2}\right)(2-\ln 2) & \leq \frac{1}{2}\left(1-\lambda_{A}^{2}\right)-\frac{1}{2} \ln 2 \Leftrightarrow \\
T^{\max } & \leq-\frac{1}{2}\left(1-\lambda_{A}^{2}\right) .
\end{aligned}
$$


Therefore, if country $A$ attracts the investor in period 1 its tax revenue in period 1 and period 2 are $-\frac{1}{2}\left(1-\lambda_{A}^{2}\right)$ and $\left(1-\lambda_{A}^{2}\right)$, respectively. Therefore the total tax revenue is equal to $\frac{1}{2}\left(1-\lambda_{A}^{2}\right)$ which is greater than what it can receive if the investor investor invests in country $B$.

Proposition 4 describes the equilibrium outcome when country $B$ receives a higher tax revenue in period 2 when country $A$ is successful in attracting the investor in period 1 . Hence, country $B$ has no incentive to undercut country $A$ unless the tax rate is positive and substantially high. This is the reason why the tax revenue of competing countries is independent of the level of restriction chosen by country $B$.

\section{Choice of Policy Restriction}

From Proposition (3) and Proposition (4), it is clear that equilibrium tax revenues of competing countries depend on the maximum of policy restriction chosen by the competing countries. Both countries receive an equal tax revenue in equilibrium. Proposition (5) below describe the levels of policy restrictions imposed by competing countries.

Proposition 5 In a subgame perfect Nash equilibrium, one of the competing countries chooses the level of policy restriction equal to 0 while the other choose a policy restriction $\lambda \in[0,1]$. Competing countries earn an equal tax revenue in equilibrium which is equal to $\frac{1}{2}$.

The proof of Proposition (5) is obvious once we note that the equilibrium tax revenue of competing countries only depends on the country with a higher level of policy restriction and it is increasing with the level of policy restriction. To keep control of the functionalities of the firm, it is necessary for a multinational to keep more than $50 \%$ ownership in a joint venture. In many countries, the level of foreign ownership in a joint venture is close to $51 \%$. It is important to note that a scenario where both countries choose no policy restriction on foreign direct investments is not a subgame-perfect Nash equilibrium. For example, China imposes a high level of restrictions on foreign investments, but it continued to attract a large share of foreign investments.

\section{Conclusion}

In a dynamic two-period model of tax competition where competing countries strategically choose the level of policy restrictions which increases sunk cost of investments, we show that choosing a greater restriction on foreign ownership is beneficial for the competing countries. A higher level of restriction on foreign ownership decreases competition in a later period and increases tax revenue. Because a country can earn more in a later period, it allows the country with a higher level of restriction offer larger tax holidays and attracts the investor in the initial period. The result is counter-intuitive as it is widely believed that 
sunk cost reduces foreign direct investments. Moreover, even though competing countries are completely symmetric ex-ante, levels of restrictions chosen by them need not be equal. One of the competing countries chose maximum possible restriction on foreign ownership while the other country can choose any feasible level of restriction on foreign ownership. The outcome is close to observed heterogeneity in levels of restrictions on foreign ownerships in different countries and sectors. A future study should look at the effect of size and cost differences between competing countries on the level of policy restrictions on foreign investments.

\section{References}

[1] Baldwin, R.E. and Krugman, P., 2004. Agglomeration, integration and tax harmonisation. European Economic Review, 48(1), pp.1-23.

[2] Bond, E.W., and L. Samuelson (1986) 'Tax holidays as signals.' American Economic Review 76, 820-6

[3] Braid, R.M., 2005. Tax competition, tax exporting and higher-government choice of tax instruments for local governments. Journal of Public Economics, 89(9), pp.1789-1821.

[4] Braid, R.M., 2013. State and local tax competition in a spatial model with sales taxes and residential property taxes. Journal of Urban Economics, 75, pp.57-67.

[5] Braid, R.M., 1996. Symmetric tax competition with multiple jurisdictions in each metropolitan area. The American economic review, 86(5), pp.12791290 .

[6] Brueckner, J.K., 2004. Fiscal decentralization with distortionary taxation: Tiebout vs. tax competition. International Tax and Public Finance, 11(2), pp.133-153.

[7] Braid, R.M., 2000. A spatial model of tax competition with multiple tax instruments. Journal of Urban Economics, 47(1), pp.88-114.

[8] Chisik, R. and Davies, R.B., 2004. Gradualism in tax treaties with irreversible foreign direct investment. International Economic Review, 45(1), pp.113-139.

[9] Calzolari, G., 2001. The theory and practice of regulation with multinational enterprises. Journal of Regulatory Economics 20, 191-211.

[10] Dasgupta, S., Sengupta, K., 1995. Optimal regulation of MNEs and government revenues. Journal of Public Economics 58, 215-234. 
[11] Desai, M.A., Foley, C.F., Hines, J.R., 2004. The cost of shared ownership: evidence from international joint venture. Journal of Financial Economics 73, 323-374.

[12] Desai, M A and J R Hines (2004) "Old rules and new realities: Corporate tax policy in a global setting", National Tax Journal, 57(4): 937-60.

[13] Davies, R. B., R. Desbordes, and A. Ray, "Greenfield versus Merger \& Acquisition FDI: Same Wine, Different Bottles?" The Institute for International Integration Studies discussion paper series 468, Trinity College, Dublin (2015).

[14] Doyle, C., van Wijnbergen, S., 1994. Taxation of foreign multinationals: a sequential approach to tax holidays. International Tax and Public Finance 211-225.

[15] Devereux, M., Lockwood, B., Redoano, M., 2008. Do countries compete over corporate tax rates? Journal of Public Economics 92, pp. 1210-1235.

[16] Eaton, J., Gersovitz, M., 1983. Country risk: economic aspects. In: Herring, R.J. (Ed.), Managing International Risk. Cambridge University Press, Cambridge, pp. $75-108$.

[17] Fredriksson, P.G. and Millimet, D.L., 2002. Strategic interaction and the determination of environmental policy across US states. Journal of Urban Economics, 51(1), pp.101-122.

[18] Golub, S.S., 2003. Measures of restrictions on inward foreign direct investment for OECD countries. OECD Economics Department Working Paper, No 357.

[19] Golub, S.S., Koyama, T., 2006. OECD's FDI regulatory restrictiveness index: revision and extension to more economies. OECD Economics Department Working Paper, No 525.

[20] Haufler; A., Mittermaier, F., Unionisation triggers tax incentives to attract foreign direct investment. The Economic Journal, 2011.

[21] Hart, O.D., Moore, J., 1990. Property rights and nature of the firm. Journal of Political Economy 98, 1119-1158.

[22] Janeba, E., 2000. Tax competition when governments lack commitment: Excess capacity as a countervailing threat. The American Economic Review, 90(5), pp.1508-1519.

[23] Janeba, E., 2002. Attracting FDI in a politically risky world. International Economic Review, 43(4), pp.1127-1155.

[24] Karabay, B., Pulverer, G., Weinmüller, E., 2009. Foreign ownership restrictions: a numerical approach. Computational Economics 33, 361-388. 
[25] Katrak, H., 1983. Multinational firms' global strategies, host country indigenisation of ownership and welfare. Journal of Development Economics $13,331-348$.

[26] Konrad, K.A. and Kovenock, D., 2009. Competition for FDI with vintage investment and agglomeration advantages. Journal of International Economics, 79(2), pp.230-237.

[27] Karabay, Bilgehan. (2010). Foreign direct investment and host country policies: A rationale for using ownership restrictions. Journal of Development Economics 93, pp. 218-225.

[28] Kesternich, I. and Schnitzer, M., 2010. Who is afraid of political risk? Multinational firms and their choice of capital structure. Journal of International Economics, 82(2), pp.208-218.

[29] Kessing, S.G., Konrad, K.A. and Kotsogiannis, C., 2007. Foreign direct investment and the dark side of decentralization. Economic Policy, 22(49), pp.6-70.

[30] Lee, Kangoh. (1997). Tax Competition with Imperfectly Mobile Capital. Journal of Urbal Economics 42, pp. 222-242.

[31] Narasimhan, Chakravarthi. (1988). Competitive promotional strategies. Journal of Business 61, 427-449.

[32] OECD. (1997). Model Tax Convention on Income and on Capital (Paris: OECD Committee on Fiscal Affairs).

[33] Rodrik D. (1997), Has Globalization Gone Too Far?, Institute for International Economics, Washington, D.C.

[34] Schnitzer, M., 1999. Expropriation and control rights: a dynamic model of foreign direct investment. International Journal of Industrial Organization $17,1113-1137$.

[35] Stoughton, N.M., Talmor, E., 1994. A mechanism design approach to transfer pricing by the multinational firm. European Economic Review 38, 143170.

[36] Schnitzer, M., 1999. Expropriation and control rights: A dynamic model of foreign direct investment. International Journal of Industrial Organization, 17(8), pp.1113-1137.

[37] Straub, S., 2008. Opportunism, corruption and the multinational firm's mode of entry. Journal of International Economics, 74(2), pp.245-263.

[38] Thomas, J., Worrall, T., 1994. Foreign direct investment and the risk of expropriation. Rev. Econom. Stud. 61, 81-108. 
[39] Wang, X., 2004. Tax evasion, tax competition and gains from nondiscrimination with equilibrium mixed strategies. Economics Letters, 83(3), pp.377381.

[40] Wilson, J.D., 2005. Tax competition with and without preferential treatment of a highly-mobile tax base. The Challenge of Tax Reform in a Global Economy, Springer, pp.193-206. 